Annette Grindsted*

\title{
Interactive resources used in research interviewing
}

\begin{abstract}
The semi-structured research interview is often critized for not producing reliable and valid results due to 1) interviewer bias, and 2) non-commitment on the part of the informants, and 3) for being an expensive information gathering tool. By applying a CA perspective in the analysis of semi-structured interview data it is shown, however, that in the present case both interviewers and informants were very much concerned with producing true, accurate and valid responses. It is shown that among the interactive resources they have at their disposal, some of them are especially suited to ensure validity and are often recurred to by both parts. They concern e.g. question-response managment, the management of pauses, and repair organization. That the semistructured research interview is an expensive information gathering tool cannot be denied. However, and all other things being equal, if validity is secured, it may turn out be a more safe research instrument than the structured interview.
\end{abstract}

\section{The research interview as talk-in-interaction}

The semi-structured research interview is a widely used research instrument in social sciences. Compared to the structured interview, which is often used to verify what people's behavior, opinions, beliefs, values, etc., are at any moment, the aim of the semi-structured interview is to gain insights in how they give meaning to their worlds in social interaction. The point of departure of this paper is, however, that the interview texts do not merely refer to some reality beyond the texts. The interview itself is interaction between an interviewer and an informant and is of interest in its own right. If it is to be considered a valid and reliable research instrument it is therefore necessary to examine how the joint construction of the interview between interviewer and informant influences the kind of knowledge produced.

* Annette Grindsted University of Southern Denmark agr@language.sdu.dk 
This paper is a study of some of the interactive resources used by interviewers and informants in their joint construction of semi-structured research interviews. One of its theoretical points of departure is that interlocutors as rational beings possess a natural predisposition to accounting. In the interview event this means that they are concerned with producing true and accurate responses. In the survey interview the interlocutors' natural inclination to demonstrate that they see themselves as being socially accountable to each other is systematically suppressed (e.g. Suchman \& Jordan 1992). In the semi-structured interview, however, they are not prevented from doing so. Consequently, what this paper intends is to demonstrate that the interviewers and informants that participated in the generation of the interview data used for the present analysis, per se were concerned with questions of veracity and validity. This will be shown through the analysis of repair interaction, question-response management, specific types of formulations used for verification purposes and of how meaning is negotiated.

\section{Data description}

The study is based on nineteen interviews made in Spanish, Danish and Swedish owned companies in Caracas, Venezuela, Guadalajara and Mexico City, Mexico, the aim being to investigate stereotypic beliefs and their importance in daily work at the intercultural work-place. The informants were all autochthonous Hispanic or Scandinavian employees at a mid-executive level. The interviews were conducted by three different interviewers. One was Venezuelan, one Swedish and one Danish. They are all researchers in their respective home countries.

\section{Research interviewing and the generation of true and valid responses}

In their study on survey interviews Suchman and Jordan (1992) consider the interview as inescapably an interactive event. On one hand the survey interview relies upon a wealth of conventions and resources from ordinary conversation, but at the same time suppresses crucial elements of ordinary conversation. They frame the contrast between the survey interview and ordinary conversation as a matter of distant, externally imposed versus local, internally produced determinations of what gets talked about in what way and by whom. Fundamentally interviewing 
procedures concern the issue of how to generate valid responses and validity requires a mechanism to assure that the parties involved in the enterprise have a common understanding of what questions mean and how the answers are to be taken. To secure validity active collaboration between the parties is required. Therefore Suchman and Jordan recommend that the interviewer should be allowed to talk about the questions, to offer clarifications and elaborations, and to engage in a limited form in recipient design and common-sense inferences. To the extent that the negotiation of meaning is suppressed resources are lost through which the intent of the questioner can be communicated or the interpretation of the respondents assessed. And in so far as the meanings of questions and responses remain uncertain, so also does the validity of the measures produced.

In her study of standardized survey interviews Hanneke HoutkoopSteenstra (2000) is also concerned with issues of validity and she also recommends greater flexibility as far as the interviewers' communicative behaviour is concerned. Among other verbal activies she suggests that interviewers should be allowed to discuss questions and answers, to accept unformatted answers and to draw and verify inferences, although she admits that such flexibility also entails certain disadvantages. It is more time-consuming and involves greater costs both as far as interviewer training, carrying through and analysing interviews are concerned.

Mazeland and ten Have (1998) argue that to allow for local negotiations concerning the meaning of questions and answers as suggested by Suchman and Jordan cannot solve the basic problem caused by the antioriented interests between interviewer and respondent in the interview situation. Even qualitative and open interviews are a practical compromise between in principle incompatible forms of life. The informant 'experiencing' and 'telling' and the interviewer 'analysing' and 'categorising'. According to Mazeland and ten Have, what conversation analysts ought to do is to suggest ways in which interviews could be conducted that take these tensions into account. They suggest that the interviewer adapts his or her questioning to the recipient and the flow of the interaction, and in accepting the answers gives a demonstration of understanding a more symmetrical format, designed for the sharing of life-world information and interests. 
As to the discursive organization of the interview data used for the present analysis they were semi-structured. In the present case this means that the interviews were based on an interview schedule with a number of both open-ended and closed questions that the interviewer was supposed to go through before the interview was concluded. The order in which the questions were raised during the interview was free and other topics than those raised by the questions could be introduced if it was found relevant. Finally, apart from asking clarifying questions, the interviewers were allowed to give feed-back to or even to comment upon the respondents answers. This gave rise to a less asymmetrical format than is normally found in semi-structured interviews, designed for leaving some room for sharing and negotiating world views.

What I intend to show in the following analyses is that in their interactive management of interview questions and responses the interviewers and informants amply demonstrate that they are concerned with issues of veracity and validity.

\section{The negotiation of meaning}

As pointed out by Suchman and Jordan (1992) the conversational dilemma of the interviewer is on one hand to elicit as much relevant information as possible bearing in mind his research interests, and on the other to avoid respond or interviewer bias. This issue is also touched upon by Mazeland and ten Have (1998) who maintain that as an interactional genre, research interviews seem to share the preference for agreement that is also generally found in ordinary conversations. They relate it to the fact that informants do not have an intrinsic interest in the research interview, for which reason interviewers are under a constant pressure to keep them motivated to continue their participation, which an open disagreement might endanger. This is one of the reasons why literature on interviewing especially urges interviewers to act in a 'neutral' fashion by refraining from evaluative comments and restricting reactions to minimal responses. As it is argued by Kvale (1996), however, even the type and intonation of minimal responses will be taken as indications of the interviewer's interest and evaluation, and will, for that reason, influence the way answers are elaborated and stories told. Interview statements are interactional products, inevitably. 
Following this line of thought, as it has been stated above, the interview is locally achieved through the talk by interlocutors. This means that questions and responses are formulated in, developed through, and shaped by the interaction between interviewer and respondent. In this way Mishler (1986) shows a number of ways through which meanings of questions and responses may be achieved from successive reformulations by interviewers and respondents until they arrive at an acceptable level of shared agreement to the insistence of interviewers on their definitions, because they are influenced by a priori assumptions about adequacy. A case to the contrary is Hutchby and Wooffitt's report on semi-structured interviews on group membership and identification, where the first exchanges were analyzed. The opening question was designed to elicit a subcultural self-categorization. Many respondents immediately did affirm the relevance of that kind of social identity. However, in several cases, the respondents' first turn was some kind of dispreferred answer. They portrayed themselves as 'not seeing the category relevance' of the interviewer's first turn, and in this way they rejected the validity of the basis on which they were selected for the interview. They were resisting the categorical affiliation which the interviewer's first turn tacitly asked them to confirm. So on the basis of the interactional management of category ascription, resistance and affiliation they were able to make some critical points on the assumption underlying the social identity theory and the purchase it affords on understanding processes of group affiliation and self-categorization (Hutchby \& Wooffitt 1998). These studies point out extreme cases of the relational alignment between interviewer and respondent in their joint construction of the interview.

The semi-structured research interview is often used for information gathering because it allows for a less imposing, more natural and spontaneous way of interaction. It cannot be ignored, however, that to ask a question in itself is a very powerful way of eliciting information. Very often an informant will accept without hesitation the premises on which a question is built. In the present study the questions rest on the presupposition that national identity is a relevant membership category to account for differences in communicative behavior at the intercultural workplace. Even category features that may or may not be related to the membership groups are introduced by the interviewer. In this way negotiation of meaning refers to national identity as a relevant 
category and to relevant category features. If we turn to the process of negotiating the thematic dimension of interviewing, fragments (1) and (2) suggest ways through which meanings of questions and responses may be arrived at. It should first be mentioned, however, that a recurrent feature of all text questions is the fact that they are very broad and general category features or open-ended questions about the organization of interactive events that should be used as a basis for categorizing memberships. What is often negotiated is not the relevance of the category features nor the interactive events themselves, but how they could be narrowed down to constitute precise and accurate descriptions of the two membership groups. If we look at fragment (1) below about argumentation technique and efficiency the central part of the question concerns efficiency. What does it mean to be efficient in argumentation and what are the membership categorizations made in this respect? The features introduced by $M$ to categorize efficiency are directness, objectivity, figures and results as far as the Danes are concerned, and emotions and talk to characterize the Venezuelans. A's question of what is meant by results is interesting. She does not only ask the question but suggests herself new shades of meaning that could be attributed to the term results, namely achievements and to get things done. These new shades of meaning are immediately accepted by $M$. Although they are not explicitly treating the dimension of efficiency or inefficiency in argumentation, one is left with the impression that the cultural attributions made by $A$ and $M$ is that the Venezuelans are not very efficient 'argumentators' whereas the Danes are, since objectivity and achievements are to be valued, but emotionality and talk without action is not.

Fragment (1)

Interviewer: A(driana)

Respondent: M(iguel)

A: es interesante eso mira y qué opinas de la técnica argumentativa que ellos usan (.) es decir

it's interesting and look what do you think about the argumentation technique they use (.) I 
cómo presentan sus argumentos de manera eficiente o poco eficiente

mean how do they present their arguments efficiently or not very efficiently

M: sí muy directos muy directos

yes very direct very direct

A: $\quad$ son directos

they are direct

M: sí seguramente directos bien objetivos en todo lo que es sus presentaciones o sea son

yes for sure direct pretty objective in every bit of their presentations that is it's presentations

presentaciones este que a lo mejor somos mientras nosotros somos emotivos y emocionales

maybe we are emotive and emotional making presentations that will appeal to another type

haciendo presentaciones que a lo mejor van a apelar::: a digamos a otro tipo de percepción

of perception you know maybe we even talk things over and over again and again we are

eh a lo mejor inclusive damos más vueltas al asunto damos una antesala como pa:ra: ir

paving the way to: let's say warm up names and all that you know they begin and present

digamos calentando nombres y todo lo demás no? ellos comienzan y dan sus resultados

their results this is the important thing

cifras resultados eso es lo importante

A: o sea lo que interesa son resultados logros

you mean what is interesting is results achievements

M: sí logros

yes achievements

A: lo hecho

things done

M: claro

that's it 
But it also occurred quite often that national identity was rejected as a valid category to account for differences in communicative behavior and in stead the informants introduced other membership categories that they found more relevant to explain perceived differences. This can be illustrated by the following fragment:

\section{Fragment (2)}

Interviewer: A(nnette)

Respondent: C(amilla)

A: hvad med: hænger de sig i protokollen øh forstår du hvad jeg mener er der særlige:

what about er do they stick to the protocol er do you understand what I mean are there

procedurer man altid skal følge særlige: arbejdsgange man skal følge og dem viger man bare

special er procedures you always have to follow special routines you follow and you just

ikke fra

don't abandon them

C: ja men der er vi så nødt til og gå tilbage og sige det det øh 'her gør vi ikk fordi nu igen det

well then we are to go back and say it it er 'here we don't because now again the fact that

der med at det er et ungt firma ikke også we are a young company you know

A: $\quad \mathrm{mm}$

$\mathrm{mm}$

C: det tager man ikke så højtideligt men de firmaer vi arbejder med we don't take it seriously but the firms we work together with

A: $\quad \mathrm{mm}$

$\mathrm{mm}$

C: hvor det faktisk er ældre indkøbschefer og så videre jo der er der meget protokol

where there actually are elderly purchasing managers and so on yes there is much protocol 
A: ok

The thematic part of the question raised by the interviewer refers to formality ('they' refers to the Venezuelans). Interactionally we find typical recipient design features such as reformulations and hesitations markers. We even find a kind of person-oriented meta statement ('do you understand what I mean'?) (cf. Section 7). What $C$ does in her reply is in the first place to generate a kind of meta statement, too, referring to something she said in reply to an earlier question ('well then we are to go back and say'). She takes up an earlier line of thought and categorically rejects that 'sticking to the protocol' forms part of Venezuelan cultural identity. Instead she introduces another set of membership categories, i.e. the younger and the older generation, where the category feature seems to apply. She is working in a young firm, where they do not stick to formalities, neither Venezuelans nor Danes. However, in Venezuelan firms with elderly staff they do. So, according to her point of view generation gaps are more important than national identity gaps to account for value mismatch. This is accepted as an adequate answer by $A$.

The analysis of the present data seems to demonstrate that the informants do not automatically accept the relevance of the categories and category features introduced by the interviewer, but showed great care and effort in offering true and accurate descriptions of how they gave meaning to their social world at the intercultural work-place.

\section{Repair organization}

In the interactive flow of ordinary conversation interlocutors, if asked a question, will under normal conditions just produce the relevant second. This is also the case in the semi-structured research interview. It happens however that the informants produce utterances in which they explicitly consider if they possess the kind of knowledge which the question invites them to talk about. When the informant in the following fragment is asked about her general opinion of the Danes, a very long response is produced, in which one of her statements is: 


\section{Fragment (3)}

Informant: (M)itz

M: yo por lo menos soy asistente de la presidencia y el presidente es danés entonces yo sí sé las diferencias (que) yo estoy viviendo I'm secretary to the management and the managing director is Danish so I do know about the differences (that) I see.....

What Mitz does is to make explicit that she considers herself to be in a position that allows her to produce a true and valid response. This is, indeed, a very marked option.

But what interactional resources may the informant recur to if (s)he thinks (s)he does not possess the kind of knowledge asked for?

Fragment (4)

Interviewer: A(driana)

Informant: M(iguel)

A: qué opinas de la competencia social de ellos son sociables o son poco sociables

what do you think about their social competence are they sociable or not very sociable

M: (2.5) es que una cosa es sociable y otra cosa es en el trabajo

(2.5) well you know one thing is sociable and another is at the job

A: umm

$\mathrm{hm}$

M: yo en a nivel sociable no los conocí fuera del trabajo socially I don't know them outside the job I don't know them

A: umm

$\mathrm{hm}$

M: fuera del trabajo no los conozco

outside the job I don't know them

A: no tuviste oportunidad nunca, you never got the opportunity,

M: no un en una sola oportunidad nada más o sea que que diría que no me atrevo a opinar en ese aspecto

no only on one occasion that's all so I would say I wouldn't dare to have an opinion in this respect 
A: claro o sea han sido relaciones puramente de trabajo of course not so you only have work relations

M: de trabajo de trabajo sí de trabajo work relations work relations yes work relations

A: $\quad$ ah y... ah and ...

We see that after $A$ has asked the interview question there is a pause of $2.5 \mathrm{sec}$. before $M$ initiates his response. He interprets the question as a matter of leisure time activities and in this context he does not know the Danes. By her next question $A$ wants to verify if she has understood him correctly and $M$ replies that he is not competent to answer the question. One might say that he is accounting for not accounting. Since he is not able to produce the projected response, he explains why it is not forthcoming and the reason is lack of knowledge. This explanation is accepted by $A$.

One thing is that the respondent is not able to produce a relevant reply for lack of knowledge. Another is that (s)he is unable to do so because (s)he does not understand the question. How may (s)he demonstrate that the question causes troubles for reasons of comprehension?

Fragment (5)

Interviewer: $\mathrm{A}$ (driana)

Informant: L(isbeth)

A: $y$ te parecen dominantes o no and do you think they are dominating or not

L: (7.0) no sé cómo dominantes dominantes que son qué (7.0) I don't know how dominating dominating that they are what

A: bueno la persona que quiere imponerse sobre los demás well a person that wants to assert himself

L: imponerse

to assert himself

A: umm

yeah

L: no

no 
A: (1.0) o sea dominante:: autoriatrio

(1.0) that is dominating:: authoritarian

L: $\quad(3.0)$ no

(3.0) no

A: no no has tenido:: ninguna experiencia no you don't you don't ha::ve any experience

L: no hasta el momento ha sido:: sea siempre con respeto y y y

no so far it has been:: well always with respect and and and

A: muy amable $(1,0)$ okej

very friendly (1.0) okey

We see that after $A$ has posed the interview question there is a pause of 7 seconds before $L$ displays that she does not understand the question in a kind of next turn repair initiator which could be seen as a self-initiated repair that invites $A$ to finish the repair by clarifying what is meant by the trouble source. After $A$ 's reformulation of the question $L$ repeats its central part and $A$ produces an acknowledgement token. Now $L$ produces only a minimal response and $A$ tries to elicit more information first by her pause and next by another kind of clarification. Again, and after a pause of 3 seconds $L$ produces a minimal response. $A$ even accounts for the almost absence of an answer. $A$ suggests that the reason why she does not add more information could be lack of knowledge. And finally $L$ produces a kind of minimal account. $A$ tries to verify if she has understood $L$ right. The absence of a response is taken to act as a confirmation. Now, to return to the question of informants' ability to produce true and accurate accounts, if they do not understand the question posed, they cannot fulfil their obligation to produce an account, and consequently they must try to remove the trouble source asking for clarification.

The fact that repair organisation is an interactional resource that informants frequently recur to seems to support the affirmation that they are concerned with issues of validity. We have so far only treated cases of lack of knowledge or lack of comprehension on the part of the informant. It also happens, however, that the trouble source is to be traced back to the interviewer, because (s)he in his or her inferential work explicitly shows that (s)he followed another trajectory than was intended by the informant. This kind of trouble source is the basis for 
the repair work made in the following fragment (arrow marks turn where repair work is initiated):

\section{Fragment (6)}

Interviewer: L(ars)

Informant: $\mathrm{A}($ ntonio)

L: e voy a hacer un par de preguntas un poco más especifíficas no, e::: en su opinión un sueco típico es individualista o no es individualista,

Er I'll ask a few a little more specific questions, er::: in your opinion a typical Swede is he individualistic or not,

A: (2.0) mi opinión es que son muy individualistas

(2.0) my opinion is that they are very individualistic

L: muy individuali

very indiviuali

A: $\quad(($ bue $))$

((we))

L: $\quad$ stas en qué sentido

stic in which sense

A: es decir te lo voy a poner como ejemplo (3.0) (RUIDO) el el por lo menos el sueco

that is I'll give you an example (3.0) (NOISE) the the at least the Swede that goes here

que viene yo no te puedo opinar sobre los suecos que viven I cannot give you an opinion of the Swedes that live

L: $\quad$ los

the

A: dentro enclavados en la sociedad sueca

in the Swedish society

L: umm

$\mathrm{hm}$

A: $\quad$ sino el sueco que viene acá

but the Swede that comes over here 
L: que viene a ( ) ( )

that comes o ( ) ()

A: exacto evidentemente (2.0) (RUIDO) hay dos cosas características de ellos (2.0) si han

exactly obviously (2.0) (NOISE) there are two characteristic things about them (2.0) if

sido enviados al exterior traen e una gran obsesión por triunfar por demostrar

they have been sent abroad they are very obsessed by making success by showing

precisamente porqué se les trajo

precisely why the were sent over

L: umjú

hhm

A: (3.0) a veces cometen el error precisamente de de perder de vista (2.5) la labor de

(3.0) sometimes they make the mistake of of losing sight of (2.5) team work

equipo (2.0) y por eso yo pienso que el sueco definitivamente o sea co sus sus metas

(2.0) and thefore I think that the Swede definitely or that his his goals for instance

por ejemplo quizá no están fincadas muchas veces en Méjico no todos pero sí una

maybe are not very often based in Mexico not all but the great majority yes or that

gran mayoría o sea por ejemplo Méjico puede ser un país intermedio en su carrera

for instance Mexico can be an intermediate country in their carreer

L: ya por eso desa desaparecen e se van, and therefore they disa disappear e they leave,

A: no no es decir me refiero a que se vuelve más individualista desde el punto de vista

no no it is I mean that they become mor individualistica from the point of view that

que es más importante para él su logro personal

his personal success is more important to him 
L: (ya entiendo) (ya entiendo)

(I understand) (I understand)

A: que el logro del equipo

than the team's success

L: (sí ya entiendo sí)

(yes I understand yes)

The interviewer asks the informant if he thinks the Swedes are individualistic or not and he produces a minimal response in the affirmative, and $L$ asks a new question inviting him to elaborate his response. Now $A$ produces an account of why he thinks the Swedes are individualistic. He thinks they go to Mexico as a step in their career building and therefore they are more interested in their personal success than in team work. This induces $L$ to state that this is the reason why they leave, and this was not what $A$ meant to say. To remove the misunderstanding he therefore makes an other-initiated other-repair. The original question was about individualism and he intended to explain why he considered them to be individualistic. He focussed on their interest in personal success and not team work. And $L$ repeatedly confirms that he understands.

It goes without saying that repair work is a very useful resource in research interviewing, since it is the only resource the interlocutors can recur to in order to eliminate trouble sources. In very asymmetrical interview situations as for instance those reported by Suchman and Jordan (1992) and by Hanneke Houtkoup-Steenstra (2000) repair work is initiated because the respondents fail to understand the question. This also holds true of the present data. The last fragment showed, however, that repair work also may be initiated due to misunderstanding on the part of the interviewer. It was even an instance of other-initiated otherrepair, and research on repair work has shown that this is a dispreferred option (Hutchby \& Wooffitt 1998). This is yet another way of showing the informants' concern with producing true and valid responses.

\section{Question-response interaction}

Literature on question design (Briggs 1986; Silverman 1995; Kvale 1996) distinguishes between different question types, e.g. open-ended questions and closed questions. Open-ended questions invites the 
informant to produce long stretches of talk with little control on the part of the interviewer on response construction. This is the typical question design in qualitative interviewing. In this connection Mazeland and ten Have (1998) report that in their corpus they see a more or less open negotiation going on in most of the questioning sequences. Massively, these negotiations concern the extendibility of the answers, and start at the moment a minimally adequate answer is given. At that moment, the interviewer could initiate a new questioning sequence, but most of the time he or she just waits for more to come or limits himself or herself to a minimal response. Closed questions, on the other hand, is a powerful means of control because they for syntactical reasons put serious constraints on the range of response options inviting the informant to produce short and minimal responses. The closed question design is typical of survey interviews. As long as respondents are not given the opportunity to elaborate on their minimal responses, e.g. yes-no answers to yes-no questions, the interviewer has no way of knowing if the question has been understood. A yes-no response merely demonstrates that the respondents have understood that the question is a yes-no question. This means that the use of e.g. yes-no questions in survey interviews poses an inherent threat to the validity of the responses (Suchman and Jordan 1992; Houtkoop-Steenstra 2000). Behavior coding studies of recorded survey interviews show that respondents provide answers that do not match the response options or say more than just 'yes' or 'no' in response to a yes-no question (Houptkoop-Steenstra 2000). This demonstrates the natural inclination on the part of the respondents to produce what they believe to be adequate and valid responses.

\subsection{Question delivery structure}

The activity of questioning may be accomplished across various turn constructional units. On the basis of data from survey interviews Houptkoop-Steenstra (2000) shows how such multi-turn questions may cause interactional troubles because the respondent upon completion of the first part of the question takes a turn to provide an answer because he or she thinks that the first possible completion point is a transition relevant place. Houtpkoop-Steenstra points out that this kind of interactional troubles may be a serious threat to validity since 
it may discourage the interviewer from asking the whole question for which reason only inadequate answers will be generated. The question delivery structure of question-answer sequences that will be analyzed in the following is one in which the open-ended and closed question types are combined. The first component is an open-ended question, and the second a closed question in which a few response options are offered, as in the fragment below:

Fragment (7)

Interviewer: A(driana)

Informant: M(iguel)

A: qué opinas de la competencia social de ellos son sociables o son poco sociables

What do you think about their social competence are they sociable or not very sociable

Following the line of thought of Houptkoop-Steenstra what could be suspected is that the informant in his role as question recipient would start production of the second projected by the open-ended questioning component immediately after its completion. But he does not, and $A$ can unhampered continue the delivery of the closed question component.

The moment the interviewer has delivered the first part of the question he reaches a possible completion point in which the informant must take into consideration if he is expected to shift his role from question recipient to response generator and consequently choose himself as next speaker, or if he should keep listening and thus continue in his role as question recipient. What could be argued in this connection is that the informant who does not take the turn at this point displays that he is a careful and attentive listener who does not intend to produce an answer until he feels sure that he has received the entire question. In the pursuance of true and accurate responses listening is an indispensable resource not only on the part of interviewers but also on the part of informants.

\subsection{Response delivery}

How do informants interactionally manage a question format in which the first part consist of an open-ended and the second a closed question? 
Do they orient towards the open-ended and/or the second component? A recurrent feature of the present data is that the opening sequence of response delivery is a closed minimal response as projected by the closed part of the question. After completion of this minimal response the interlocutors have reached a crucial moment in response construction. The interviewer has posed a closed question whose syntactical, formal constraints imply that the relevant second is a closed, minimal response. But what about the open-ended part of the question? Although Mazeland and ten Have (1998) do not mention the type of interview schedule questions that were used in their corpus, they found that as far as the negotiation of the extendibility of responses is concerned, most of the time the interviewer in displaying active listening (Kvale 1996) just waited for more to come or limited him or herself to a minimal response. In this connection two comments are relevant. In the first place most of the time question recipients are normatively oriented towards producing responses that correspond to what is projected by the question. In this way they design their responses so that they structurally correspond to the question. This means that in the present case a closed, minimal response is of course a relevant second, but it could hardly be considered to be a complete and adequate response. In this way if a response component that is sequentially linked to the open-ended part of the question is not produced the interviewer would consider it to be noticeably absent. This implies that the informant is expected to extend his minimal response on his own initiative, and this is, in fact, what happens in the following fragment (arrow marks relevant turn):

\section{Fragment (8)}

Interviewer: A(nnette)

Informant: H(éctor)

A: qué opinas de la técnita técnica argumentative de los e daneses a nie si hay algú algún

what do you think about the er Danes' argumentation techni technique a nie if there is

problema que que resolver y cuá cuál cuál es su técnica argumentativa presentan sus

som some kind of problem to be solved and ho how how is their argumentation 
argumenta e sus argumenta sus argumentos de forma eficiente o poco eficiente.

technique do they present their argume er their argumenta efficiently or not very efficiently.

$\mathrm{H}: \rightarrow$ son muy eficientes s el danés es una persona muy culta they are very efficient $\mathrm{s}$ the Dane is a very educated person

A: umjú

$\mathrm{hm}$

H: que lee mucho y de mucho más experiencia que que que el mejicano en (esos)

who reads a lot and have a lot of experience that that that the Mexican en (these)

entonces sus argumentos son siempre basados en cosas científicas o experiencias...

so his arguments are always based on cientific things or experience...

As far as question structure is concerned we see that the first part is an open-ended component, and the second closed, and we note that $H$ does not start constructing his answer until $A$ has finished the interview schedule question. In delivering his response $H$ first orients towards the second question component producing a closed, minimal response and immediately afterwards he extends the answer on his own initiative producing an account. Note that $A$ 's continuer is not produced immediately after the closed, minimal response, but not until first completion point of account construction inviting $H$ to add more information.

The second comment is about turn transition. We know from studies of ordinary conversation that the time lapse involved in speaker change is minimal. On one hand there is a preference for only one speaker at a time and on the other for always one interlocutor producing talk. However, the data used for the present study point in the direction that the interactive flow is somewhat slowed down in the sense that pauses are frequent and relatively long (up to 7 seconds). However, as far as pause length is concerned, the longest pauses are not produced in connection with question delivery and closed response generation but immediately after the minimal, closed response has been produced. It may be argued that these rather long pauses belong to the informant, since at this point in response delivery he has oriented himself only towards the closed 
part of the question. In the above fragment, however, the time lapse between the minimal response component and the open-ended response component could hardly be called a pause. The interviewer is not even being given the opportunity to use waiting as a resource to prompt an answer. Rather the informant on his own initiative chooses himself as next speaker to produce a response that is also directed towards the open-ended part of the interview schedule question. As far as the way in which the informant in the above fragment interactively manages the open-component-closed-component question delivery is concerned it could be stated that he displays a great willingness and ability to produce an adequate and complete answer on his own initiative both in his role as question recipient and response generator.

As it was stated above, in the present data pauses following projected closed, minimal responses are found to be relatively longer than those involved in speaker change. This could be explained by the fact that closed questions cognitively are much easier to cope with than open-ended questions, where informants generally will not have ready answers. This seems to be supported by the preferred response component order, where the closed part is followed by the open-ended part.

Returning to the issue of question delivery it might seem contradictory to pose question components that work in opposite directions, one inviting to produce a closed response, and another to produce an open-ended response. Why this discrepancy in the discourse identities displayed by the interviewer as both a closed question 'asker' who in his formulation of questions sets up a few categories thus inviting to a few canonical response options, and an open-ended question 'asker', who preferred to do account recipiency. One possible explanation has to do with recipient design. Closed questions offering only a few response options invite to a deductive way of thinking that are cognitively much simpler to cope with than open-ended questions, where informants may not at first be able to take a comprehensive view of the issue raised by the question. In this way the closed question format may trigger off a train of thoughts that is a precondition for doing accounting at all. This explanation seems to be supported by the sequential order of the response components. The first thing the informants did was to introduce a 'closed' minimal response to which they added an extension that served as a kind of explanation and not the inverse order. They 
did not delay the minimal response in order to introduce the reasons to support the minimal response first.

\section{Verification}

As mentioned by Kvale (1996), interviewers who know what they are asking about, and why they are asking, will attempt to clarify the meanings relevant to the research project during the interview obtaining a disambiguation of the statements made, and thereby providing a more trustworthy point of departure for the later analysis. Ideally, the testing of hypotheses and interpretations is finished by the end of the interview with the interviewer's hypotheses having been verified or falsified during the interview. Verification is an important interactive resource in the generation of true and accurate responses. In this way, in the processing of information interviewers often use formulations which offer a summarizing interpretation of the locally relevant tenor of the just provided talk. They help to establish a shared sense of what the answers really mean. As described by Mazeland and ten Have (1998) formulations are sequentially implicative: the informant has the right to decide on their adequacy. Therefore they could be considered to be first-pair-parts of and adjacency pair Formulation/Decision. As a first part of that pair type, they project the continuation of the current topic over at least two subsequent turns, the present formulation and the expectable decision. Heritage (1985) describes cooperative recycles as a type of formulation which seems to be particularly relevant for the semi-structured research interview. In cooperative recycles the tenor of the preceding utterance is expanded in a way that probably is agreeable to the informant; the recipient just assists the speaker in making his or her point utterly clear. They use a request for confirmation format; by submitting an assertion concerning the informant's previous utterance who is an expert on its meaning, a decision on their meaning is invited.

One of the interactive features that distinguishes the interview from other forms of talk is its fragmentation into question-answer pairs that seem to be totally independant of each other. From a sequential point of view the interview, like any other form of talk unfolds on a turn-toturn basis where one turn sets up expectations as to what kind of turn is to follow. This sequential implicativeness implies that coherence is 
locally achieved and is studied as very local phenomenon. This implies, in turn, that if interlocutors want to refer to talk that was produced before the immediately preceding utterance, a special job has to be done. Using Stubbs's conceptual framework (1983) this can be done by using a misplacement marker that announces that what follows is not only sequentially linked to the previous turn. Among the type of misplacement markers identified by Stubbs in committee meeting interaction, especially two types are relevant for the present study, i.e. selfreferential metastatements and metareference to other speaker's talk. In fragments (9) and (10) that follow there is an example of formulations that refer to own previous talk and to the other speaker's talk and that are sequentially linked both to the previous turn and something uttered by the informant prior to that (arrow marks relevant turn).

\section{Fragment (9)}

Interviewer: A(nnette)

Informant: $\mathrm{C}($ amilla)

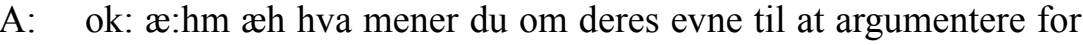
en sag

okey um: um what do you think about their ability to argue for a cause

C den er som regel god altså der der er jo ikke den ting som lige pludselig ikke kan hive

usually it's good there isn't the thing you know that they suddenly they pull out the hat um: often

ind som et argument æh tit så får man blandet sin sin bedstemor og fodbolden ind i det

you get your grandmother and football mixed up into it ((laughing))

A: (laughing)

hvor vi starter med at argumentere et eller andet ikk og så lige pludselig sådan altså

where we begin to argue for something you know and then all of a sudden well I don't know if the

jeg ved ikke hvis de tænker sådan på saglige argumenteren og vi snakker om 'det her

think of like factual or objective arguments and we are talking about this tiny problem in this case it 
lille problem der kan det være svært lisom måske at holde igen opmærksomheden og

may sometimes be difficult to keep paying attention and to concentrate on this tiny problem

koncentrationen om 'det lille problem for så kommer der altså nogle andre ting der

for then there're some other things that are included and that are relevant to them

bliver draget ind i det og som for dem har relevans

A: $\rightarrow$ det var de du startede med at sige omkring

this was what you started by saying about

C: ja

yes

A: strukturering

structuring

C: ja ja

yeah yeah

A: dit første indtryk

your first impression

$\mathrm{C}: \mathrm{mm}$

h'm

\section{Fragment (10)}

Interviewer: L(ars)

Informant: M(iguel)

L: pero a un mejicano o a un mejicano normal bueno de esa empresa le resulta fácil o

but to a Mexican or to a normal Mexican well from this firm is it easy or difficult

difícil comunicarse con un sueco o ahora pienso quizá comparando con

to communicate with a Swede or now I think perhaps comparing with

norteamericano alemán etcétera etcétera el sueco presenta dificultades generales por 
Northamerican German etcetera etcetera does the Swede present general problems so

así decirlo en la comunicación e: por ejemplo no se le nota reacciones que sí se le

to speak in communication er for instance you don't see his reactions yes you see

notan muy bien sus reacciones o que en el lenguaje corporal o bueno todo

his reactions very well or that in body language or everything

M: umjú

$\mathrm{hm}$

L: el conjunto

taken together

M: umjú

$\mathrm{hm}$

L: de del ( ) comunicarse in communicating

M: sí sí

yes yes

L: con alguien

with somebody

M: no

no

L: qué qué le parece, what what do you think,

$\mathrm{M}: \rightarrow$ no creo yo creo que el sueco por lo que explicaba anteriormente el det tener que

I don't think I think that the Swede due to what I explained before the fact that he has er

haberse e abierto a pues a una Europa primero con un montón de de idiomas

opened up to a well a Europe first with lots of of different languages expressions and

diferentes expresiones y desde luego también hacia el resto del mundo yo creo que 
of course also to the rest of the world I think that Sweden is the most transnational country

Suecia es el país más transnacional que existe por todas las grandes compañías que

that exists because of all the big companies it has and I think that there are not

tiene y yo creo que no hay otro país tan gran tan transnacional per cápita como Suecia

other countries as big as transnational per inhabitant as Sweden

In fragment (9) the informant is asked about the Venezuelans' ability to argue for a cause. In her response the gist of her argument is that they find it difficult to keep attention and to concentrate on a specific problem. The factual basis of discussion is sometimes slipping because all kinds or arguments are introduced. How does the interviewer treat this statement? She reintroduces the topic of structuredness and makes a kind of meta-referential comment to something stated earlier by the informant, and tries in this way to verify comprehension. It could be described as a kind of inferential work, in which she tries to link together parts of the immediately preceding utterance with something that the informant replied to an earlier question. In this way her comment is both of local and global relevance in the sense that she suggests a way in which the informant's statements may form a coherent whole centering around the topic of structuredness. The informant treats the comment as a request for confirmation and does confirm that structuredness and the Venezuelans' difficulties in keeping attentention and concentrating themselves are bound up with each other.

In fragment (10) the informant is asked if he thinks it is easy or difficult to communicate with the Swedes. What he does after having produced the closed, minimal response is to refer to something he explained in an earlier statement. In this way he is making a kind of self-referential formulation where Swedish openness towards the world is of local relevance as a response to communication ability and at the same time of global comprension relevance since it can explain other aspects of Swedish cultural identity as well. In this way the informant himself tries to facilitate or verify comprehension across questionanswer pairs and demonstrates that he is also concerned with producing consistent and valid responses. 


\section{Conclusion}

If we accept the idea that the construction of the social world takes place in the local management of context and meaning in conversation, the interview turns out to be an interactive event that is of interest in its own right. Since it is also an information gathering research tool we must of course also be concerned with matters of validity. For many years it has been generally acknowledged that to avoid response bias interviewers interactionally had to proceed in a fashion that was as neutral as possible. We must accept, however, that 'neutrality' is not possible, since even very subtle intonation cues, the use of continuers or acknowledgement tokens or other kinds of minimal responses produced by interviewers will influence the way in which informants construct responses. It could also be argued that restricting the interactive repertoire of interviewers may be a threat to validity. With a view to maximizing validity several interview data researches have recommended an expansion of interviewers' interactive repertoire to allow for a more symmetrical format. Such was the format of the interview data used for the present study. The aim of the study was from a conversation analytical perspective to analyse some of the resources interviewers and informants recurred to in their joint construction of the interviews. It was based on the presupposition that the interlocutores as rational beings per se are concerned with matters of accountability. Therefore, from the very moment that have accepted to engage in a research interview, they will automatically make every effort to produce true and accurate responses. Among the interactive resources interlocutors recur to, especially four were analyzed. They were phenomena related to the negotiation of meaning, questionresponse interaction, repair organization and verification. It turned out that both interviewers and informants were highly concerned with producing valid, accurate and consistent responses, not only within but also across question-answer pairs. It can therefore be concluded that in semi-structured research interviews of the present type, allowing for a certain extent of sharing and negotiating world views, may enhance issues of validity. As it is stated by Mazeland and ten Have (1998), interviewers and informants basically have different agendas. However, allowing for a more ordinary conversation-like interactive format may situate the interlocutors on a more equal level where they both feel they have a joint commitment to produce true knowledge. 


\title{
Transcription key
}

\author{
. indication that an utterance is finished (falling entonation) \\ , rising entonation \\ ? questioning entonation \\ (figure) pause \\ ( ) inaudible speech \\ (word) transcribers' guess \\ :: $\quad$ prolonged sound \\ (( )) non-verbal activities, e.g. laughs
}

It should be mentiond that the transcriptive detail of each fragment has been adapted to the interactive phenomena it is meant to illustrate.

\section{References}

Antaki, Charles 1994: Explaining and Arguing - The Social Organization of Accounts. London: Sage Publications.

Antaki, Charles; Widdicombe, Sue (eds.) 1998: Identities in Talk. London: Sage Publications.

Baker, Carolyn 1998: Membership Categorization and Interview Accounts. In Silverman, David (ed.): Qualitative Research. Theory, Method and Practice. London: Sage Publications, 130-144.

Briggs, Charles L. 1995: Learning how to ask. A sociolinguistic appraisal of the role of the interview in social science research. Cambridge: Cambridge University Press.

Buttney, Richard 1993: Social Accountability in Communication. Newbury Park, Cal: Sage Publications

Fant, Lars M 2000: Managing social distance in interviews: a study on identity negotiation. Paper read at IprA conference, Budapest. 1-25.

Ford, Celia E; Thompson, Sandra A. 1996: Interactional units in conversation: syntactic, intonational, and pragmatic resources for the management of turns. In Ochs, Schegloff, Thompson (eds.): Interaction and Grammar. Cambridge: Cambridge University Press, 134-185.

Grindsted, Annette 2000: Stereotypes in action. In Odense Working Papers on Language and Communication, No. 19, 33-51.

Grindsted, Annette 2001: The discursive organization of research interviews. In Hermes Journal of Linguistics, 27-2001. 173-192.

Houtkoop-Steenstra, Hanneke 2000: Interaction and the Standardized Survey Interview. The living questionnaire. Cambridge: Cambridge University Press. 
144

Houtkoop-Steenstra, Hanneke; Mazeland, Harrie 1985: Turns and discourse units in everyday conversation. In Journal of Pragmatics, 9. 595-619.

Hutchby, Ian; Wooffitt, Robin 1998: Conversation Analysis. Principles, Practices and Applications. Oxford: Polity Press.

Kvale, Steiner 1996: Interviews. An Introduction to Qualitative Research Interviewing. Thousand Oaks. Sage Publications.

Mazeland, Harrie; Have, Paul ten 1998: Essential Tensions in (Semi)-open Research Interviews. http://www.pscw.uva.nl/emcal/ET.htm. 1-12.

Mishler, Elliot G. 1986: Research Interviewing. Context and Narrative. Cambridge, Mass.: Harvard University Press.

Schegloff Emanuel A. 1996: Turn organization: one intersection of grammar and interaction. In Ochs, Schegloff, Thompson (eds.): Interaction and Grammar. Cambridge: Cambridge University Press, 52-134.

Silverman, David 1995: Interpreting Qualitative Data. Methods for Analysing Talk, Text and Interaction. London: Sage Publications.

Suchman, Lucy; Jordan, Birgitte 1992: Validity and the Collaborative Construction of Meaning in Face-to-Face Surveys. In Tanur, Judith M. (ed.): Questions about Questions. New York: Russel Sage Foundation, 241-267. 